\title{
Changes in uterine phosphatase levels in mice deprived of LH during early pregnancy
}

\author{
Geeta Parathasarathy, Tarala Purandare, Bakhtawar Katrak, \\ H. S. Juneja and Safia R. Munshi \\ Institute for Research in Reproduction, Parel, Bombay 400012, India
}

\begin{abstract}
Summary. Mice injected with normal rabbit serum on Day 4 of gestation showed a progressive increase in specific alkaline and acid phosphatase activities on Days 6 and 7. Mice injected with antiserum to LH on Day 4 showed a significant decrease in specific alkaline phosphatase activity estimated biochemically on Days 6, 7 and 8 , but this decrease was histochemically evident only on Day 8 . Similarly, acid phosphatase activity in antiserum-treated mice was significantly increased on Days 6,7 and 8 when estimated biochemically, but only on Day 8 when studied histochemically.
\end{abstract}

\section{Introduction}

In mammals, induction of blastocyst implantation is a critically timed event dependent on the sequential interplay of two hormones, oestrogen and progesterone. Intervention at the earliest possible stage after fertilization, e.g. before implantation or soon afterwards, would be a useful and direct approach towards the control of early pregnancy.

A single injection of an antiserum to LH on Day 4 of pregnancy in mice results in the termination of pregnancy (Munshi, Purandare \& Rao, 1972). Subsequent studies (Munshi \& Nilsson, 1973) using glutaraldehyde-perfused tissues, however, revealed that the attachment reaction and blastocyst implantation occurred normally in antiserum-treated mice. Nevertheless, termination of pregnancy occurred on Day 8 of gestation due to massive haemorrhage in the decidua. A single injection of the antiserum given on Day 4 of pregnancy was unable to block the mitotic shift from epithelial to stromal cells, which normally occurs on Day 4 of pregnancy (Munshi et al., 1973). Since no morphological change was evident in the implanting blastocyst or the immediate surrounding uterine tissue in mice deprived of $\mathrm{LH}$, an attempt was made to study the enzymic changes induced in these tissues.

It is well established that alkaline and acid phosphatases are associated with the decidual cell reaction and play an important role in implantation (Finn \& Hinchcliffe, 1964; Lobel, Tic \& Shelesnyak, 1965a, b, c, d, e; Manning, Carter \& Butler, 1969; Malinowska \& Fotherby, 1975; Johnson, Calarco \& Siebert, 1977). In the present study the activities of acid (EC 3.1.3.2) and alkaline (EC 3.1.3.1) phosphatase in the implantation sites of mice injected with antiserum to $\mathrm{LH}$ were estimated biochemically and histochemically.

\section{Materials and Methods}

Fertile female mice of the Swiss strain, weighing between 20 and $25 \mathrm{~g}$, were used. The animals were maintained in air-conditioned rooms with a $14 \mathrm{~h}$ light $/ 24 \mathrm{~h}$ schedule. The females were caged with fertile males on the afternoon of pro-oestrus and checked the next morning for the presence of a vaginal plug. The day on which a vaginal plug was observed was considered as Day 1 of pregnancy. 
Antiserum to LH was prepared in rabbits by the method of Munshi \& Rao (1965). At 10:00 h on Day 4 of gestation, the control animals were injected subcutaneously with $0.2 \mathrm{ml}$ normal rabbit serum and the experimental animals with an equal volume of the LH antiserum. The animals were autopsied at 11:00 h on Days 6,7 and 8. Pontamine blue dye was injected through the tail vein before autopsy to facilitate detection of implantation sites. For histochemical studies the implantation sites were immediately frozen and $8 \mu \mathrm{m}$ sections were cut on a Pearse Slee Cryostat at $-22^{\circ} \mathrm{C}$. The sections were fixed in chilled acetone $\left(-4^{\circ} \mathrm{C}\right)$ and were stained for acid and alkaline phosphatase activities by Gomori's methods as reported by Pearse (1961). The enzyme activity was graded by visual appraisal of the staining reaction from moderate $(+)$ to intense $(++++)$.

For biochemical estimations, the implantation sites were homogenized to $1 \%$ in $0.9 \%$ (w/v) sodium chloride. Protein was estimated by the method of Lowry, Rosebrough, Farr \& Randall (1951). Optical density was measured at $540 \mathrm{~nm}$ on a Gilford spectrophotometer. The activities of acid and alkaline phosphatases were estimated by the $p$-nitrophenol phosphate method of Bessey, Lowry \& Brock (1946). Optical density was measured at $400 \mathrm{~nm}$ and the enzyme activities were expressed as units where 1 phosphatase unit is the amount of enzyme which liberates $0.05 \mathrm{mmol} p$-nitrophenol at $37^{\circ} \mathrm{C}$ for $30 \mathrm{~min}$. For alkaline phosphatase activity, the values are multiplied by the correcting factor of 20 and for acid phosphatase activity they are multiplied by the correcting factor of 4.68 .

The statistical significance of differences between the means was determined by Student's $t$ test and $P$ values of $<0.05$ were considered significant.

\section{Results}

The histochemical localization of phosphatase activity in the decidual tissue of the control and experimental mice is depicted in Table 1. In the control animals alkaline phosphatase activity increased between Days 6 and 7, while acid phosphatase activity remained constant. In the mice treated with LH antiserum, alkaline phosphatase decreased markedly on Day 8 but acid phosphatase activity became intense on Day 8 of pregnancy when compared to the controls.

Table 1. Histochemical localization of alkaline and acid phosphatase activity* in mouse implantation sites

\begin{tabular}{|c|c|c|c|c|c|c|}
\hline \multirow[b]{2}{*}{ Phosphatase } & \multicolumn{3}{|c|}{ Control mice } & \multicolumn{3}{|c|}{ Mice injected with $\mathrm{LH}$ antiserum } \\
\hline & Day 6 & Day 7 & Day 8 & Day 6 & Day 7 & Day 8 \\
\hline Alkaline & ++ & +++ & +++ & ++ & $+t$ & + \\
\hline Acid & ++ & ++ & ++ & ++ & ++ & ++++ \\
\hline
\end{tabular}

* Estimated on a 4-point scale: + , moderate; ++ , good $;+++$, high $;++++$, intense.

Biochemical estimations of the phosphatase activities are given in Table 2. A progressive increase in the wet weight and total protein content of the uterus was observed in the control mice from Days 6 to 8. This increase was significantly inhibited in mice treated with LH antiserum. In control mice, there was a rise in specific alkaline and acid phosphatase activities from Days 6 to 7, but the activities remained unchanged on Day 8. In the antiserum-injected mice a significant decrease in alkaline phosphatase activity was observed on Days 6,7 and 8 when compared with the respective controls. On the other hand, a significant increase in acid phosphatase activity occurred for all 3 days when compared with the respective controls. 
Table 2. Biochemical estimation of alkaline and acid phosphatase in mouse implantation sites

\begin{tabular}{|c|c|c|c|c|c|c|}
\hline & \multicolumn{3}{|c|}{ Control mice } & \multicolumn{3}{|c|}{ Mice injected with $\mathrm{LH}$ antiserum } \\
\hline & Day 6 & Day 7 & Day 8 & Day 6 & Day 7 & Day 8 \\
\hline & \multicolumn{6}{|c|}{ Alkaline phosphatase } \\
\hline No. of animals & 13 & 10 & 8 & 11 & 8 & 9 \\
\hline Uterine wt (mg) & $25.92 \pm 1.95^{\mathrm{a}}$ & $38.44 \pm 2.00^{b}$ & $54.67 \pm 3.51^{\mathrm{c}}$ & $18.00 \pm 0.90^{c}$ & $19.81 \pm 2.87^{d}$ & $20.88 \pm 2.40^{d}$ \\
\hline Total protein (mg) & $1.41 \pm 0.10^{\mathrm{a}}$ & $1.71 \pm 0.18^{\mathrm{a}}$ & $2.35 \pm 0.21^{\mathrm{b}}$ & $1.06 \pm 0.05^{\mathrm{c}}$ & $1.04 \pm 0.10 \mathrm{c}$ & $1.02 \pm 0.19^{c}$ \\
\hline Total enzyme activity & $76.80 \pm 21.40^{\mathrm{B}}$ & $448 \cdot 60 \pm 40 \cdot 6^{b}$ & $589.00 \pm 95.90^{\mathrm{b}}$ & $24.40+4.40^{c}$ & $52 \cdot 20 \pm 16 \cdot 60^{d}$ & $39 \cdot 80 \pm 5 \cdot 80^{c}$ \\
\hline \multicolumn{7}{|l|}{ Specific enzy me activity } \\
\hline Units/mg protein & $48 \cdot 00 \pm 10 \cdot 60^{n}$ & $278.40 \pm 32.40^{b}$ & $260 \cdot 00 \pm 42.00^{\mathrm{b}}$ & $22 \cdot 00 \pm 3 \cdot 60^{c}$ & $44.00 \pm 9 \cdot 60^{d}$ & $44 \cdot 00 \pm 10 \cdot 20^{d}$ \\
\hline \multirow[t]{2}{*}{ Units/mg tissue } & $2.46 \pm 0.54^{\mathrm{a}}$ & $11.20 \pm 0.54^{\mathrm{b}}$ & $10 \cdot 60 \pm 1 \cdot 38^{\mathrm{b}}$ & $1.20 \pm 0.22^{c}$ & $2.54 \pm 0.56^{\mathrm{d}}$ & $2.06 \pm 0.32^{\mathrm{d}}$ \\
\hline & \multicolumn{6}{|c|}{ Acid phosphatase } \\
\hline No. of animals & 6 & 8 & 7 & 5 & 8 & 7 \\
\hline Uterine wt (mg) & $27.43 \pm 1.52^{\circ}$ & $42 \cdot 20 \pm 2.849^{b}$ & $46 \cdot 37 \pm 4 \cdot 53^{b}$ & $16 \cdot 04 \pm 1 \cdot 10^{c}$ & $21 \cdot 35 \pm 3.63^{c}$ & $17.31 \pm 1.55^{\mathrm{c}}$ \\
\hline Total protein (mg) & $1.35 \pm 0.09^{\mathrm{a}}$ & $1.70 \pm 0.29^{\mathrm{a}}$ & $1.82 \pm 0.27^{\mathrm{a}}$ & $1.01 \pm 0.07 \mathrm{~b}$ & $0.71 \pm 0.13^{\mathrm{b}}$ & $0.73 \pm 0.11^{b}$ \\
\hline Total enzyme activity & $17.17 \pm 1.54^{\circ}$ & $27.09 \pm 3.68^{b}$ & $20.45 \pm 4.21^{\mathrm{c}}$ & $16.28 \pm 1.26^{\circ}$ & $24.47 \pm 3.94^{\mathrm{b}}$ & $18.25 \pm 1.85^{\mathrm{c}}$ \\
\hline \multicolumn{7}{|l|}{ Specific enzyme activity } \\
\hline Units/mg protein & $12 \cdot 60 \pm 1 \cdot 30^{\mathrm{a}}$ & $17 \cdot 70 \pm 2 \cdot 30^{\mathrm{b}}$ & $11 \cdot 20 \pm 2 \cdot 10^{\mathrm{s}}$ & $15.90 \pm 1 \cdot 10^{c}$ & $38.80 \pm 5 \cdot 60^{d}$ & $29 \cdot 40 \pm 7 \cdot 30^{d}$ \\
\hline Units/mg tissue & $0.63 \pm 0.05^{\mathrm{a}}$ & $0.63 \pm 0.06^{a}$ & $0.44 \pm 0.09^{\circ}$ & $1.01 \pm 0.06^{b}$ & $1.16 \pm 0.05^{b}$ & $1.03 \pm 0.03^{\mathrm{b}}$ \\
\hline
\end{tabular}

Values are mean \pm s.e.m.

In each horizontal row, values with different superscripts are significantly different, $P<0.05$.

\section{Discussion}

A marked increase in protein synthesis in the uterus on Day 4 of pregnancy in the mouse (Gwatkin, 1969; Aitken, 1977; Pratt, 1977), accompanied by a 10-17-fold increase in the activity of alkaline phosphatase in the decidual tissue at the site of implantation (Pritchard, 1947; Christie; 1966; Manning, Meli \& Steinetz, 1966; Steinetz, Manning, Giannina \& Meli, 1967; Jelinek \& Jelinkova, 1975), indicates the preparation of the endometrium for implantation of the arriving blastocyst, and suggests that alkaline phosphatase is an important marker enzyme for the decidual cell reaction and could be intimately associated with implantation. Acid phosphatase, which has been shown to increase on Day 6 of pregnancy, is associated with the breakdown and phagocytosis of luminal epithelial cells at the site of implantation (Smith \& Wilson, 1971; Malinowska \& Fotherby, 1975; El-Shershaby \& Hinchliffe, 1975).

In the present study, the increase in the wet weight and total protein content of the uterus was associated with an increase in the phosphatase activities in the implantation site of the control mice between Days 6 and 7 and thus confirms the earlier observations (Finn \& Hinchliffe, 1964; El-Shershaby \& Hinchliffe, 1975; Aitken, 1977). However, in the antiserumtreated mice, a decrease in total protein and uterine weight was observed. This was accompanied by a concurrent decrease in alkaline phosphatase and an increase in acid phosphatase levels when measured biochemically and compared to the respective controls on all 3 days studied, but the changes were evident histochemically only on Day 8. Lobel et al. (1965e) have observed a similar rise in acid phosphatase and a loss of alkaline phosphatase activities in rats treated with specific inhibitors for decidualization (MER-25, pyrathiazine or ergocornine) during pregnancy and pseudopregnancy, suggesting that changes in the two phosphatases were associated with decidual cell regression.

Alkaline phosphatase plays an important role in transferring metabolites across the cell membrane. Its high activity in the decidual tissue, associated with high protein synthesis, reflects its nutritive role for the developing blastocyst and thereby helps in the maintenance of pregnancy. Decreases in alkaline phosphatase activity, together with a decrease in total protein in the antiserum-treated animals in the present study, suggest deprivation of nutrient material to the blastocyst, inhibiting its growth and survival and resulting in the termination of pregnancy. Acid phosphatase is a lysosomal enzyme associated with the breakdown and 
phagocytosis of the tissue. The significant increase in acid phosphatase activity in the antiserumtreated animals would indicate enhanced phagocytosis of the luminal epithelial cells accompanied by degeneration of the growing blastocyst and termination of pregnancy. The biochemical method of assessment of phosphatase activity, being more sensitive and quantitative, is able to demonstrate these changes well.

The Pearse Slee Cryostat and the chemicals used in the present study were obtained from a grant to the WHO CCCR, Bombay.

\section{References}

Aitken, R.J. (1977) Changes in the protein content of mouse uterine flushings during normal pregnancy and delayed implantation and after ovariectomy and oestradiol administration. J. Reprod. Fert. 50, 29-36.

Bessey, O.A., Lowry, O.H. \& Brock, M.J. (1946) J. biol. Chem. 164, 321. Cited in Methods of Enzymatic Analysis, (1965), pp. 783-785. Ed. H. U. Bergmeyer. Academic Press, New York.

Christie, G.A. (1966) Implantation of the rat embryo: glycogen and alkaline phosphatases. J. Reprod. Fert. 12, 279-294.

El-Shershaby, A.M. \& Hinchliffe, J.R. (1975) Epithelial autolysis during implantation of the mouse blastocyst: an ultrastructural study. J. Embryol. exp. Morph. 33, 1067-1080.

Finn, C.A. \& Hinchliffe, J.R. (1964) Reaction of the mouse uterus during implantation and deciduoma formation as demonstrated by changes in the distribution of alkaline phosphatase. J. Reprod. Fert. 8, 331-338.

Gwatkin, R.B.L. (1969) Nutritional requirement for post-blastocyst development in the mouse: amino acids and proteins in the uterus during implantation. Int. J. Fert. 14, 101-105.

Jelinek, J. \& Jelinkova, M. (1975) Changes in the endometrial enzymes of rats during oestrous cycle and early pregnancy. Acta endocr., Copenh., Suppl. 199, 273. Abstr.

Johnson, L.V., Calarco, P.G. \& Siebert, M.L. (1977) Alkaline phosphatase activity in preimplantation mouse embryo. J. Embryol. exp. Morph. 40, 83-89.

Lobel, B.L., Tic, L. \& Shelesnyak, M.C. (1965a) Studies on the mechanism of nidation. XVII. Histochemical analysis of decidualization in the rat. Part I: Oestrous cycle and pseudopregnancy. Acta endocr., Copenh. 50, 452-468.

Lobel, B.L., Tic, L. \& Shelesnyak, M.C. (1965b) Studies on the mechanism of nidation. XVII. Histochemical analysis of decidualization in the rat. Part 2: Induction. Acta endocr., Copenh. 50, 469-485.

Lobel, B.L., Tic, L. \& Shelesnyak, M.C. (1965c) Studies on the mechanism of nidation. XVII. Histochemical analysis of decidualization in the rat. Part 3: Formation of deciduomata. Acta endocr., Copenh. 50, 517-536.

Lobel, B.L., Tic, L. \& Shelesnyak, M.C. (1965d) Studies on the mechanisms of nidation. XVII. Histochemical analysis of decidualization in the rat. Part 4: Regressions of deciduomata. Acta endocr.,
Copenh. 50, 537-559.

Lobel, B.L., Tic, L. \& Shelesnyak, M.C. (1965e) Studies on the mechanism of nidation. XVII. Histochemical analysis of decidualization. Part 5: Uterine manifestations of interference with hormonal requirements of deciduomata. Acta endocr., Copenh. $50,560-583$.

Lowry, O.H., Rosebrough, N.J., Farr, A.L. \& Randall, R.J. (1951) Protein measurement with the Folin phenol reagent. J. biol. Chem. 193, 265-267.

Malinowska, K.W. \& Fotherby, K. (1975) Enzymic activity in rat uterus during early pregnancy. Hormone Res. 6, 95-104.

Manning, J.P., Meli, A. \& Steinetz, B.G. (1966) Alkaline phosphatase and glucuronidase activity in the rat uterus during early pregnancy. $J$. Endocr. 35, 385-391.

Manning, J.P., Carter, S.G. \& Butler, M.C. (1969) Artificial stimulatory and hormonal requirements of decidual ALP in pseudopregnant rat. Acta endocr., Copenh. 61, 164-172.

Munshi, S.R. \& Nilsson, O. (1973) Morphological effect of antiserum to luteinizing hormone on early pregnancy in mice. J. Reprod. Fert. 33, 127-128.

Munshi, S. R. \& Rao, S.S. (1965) An immunological study of sheep pituitary luteinizing hormone. Indian J. exp. Biol. 3, 136-138.

Munshi, S.R., Purandare, T.V. \& Rao, S.S. (1972) Effect of antiserum to ovine luteinizing hormone on corpus luteum function in mice. J. Reprod. Fert. 30, 7-12.

Munshi, S.R., Purandare, T.V. \& Rao, S.S. (1973) Effect of antiserum to ovine luteinizing hormone on uterine cell division during early pregnancy in mice. J. Endocr. 58, 123-124.

Pearse, A.G.E. (1961) Histochemistry, Theoretical and Applied, 2nd edn. Little, Brown \& Co., Boston.

Pratt, H.P.M. (1977) Uterine proteins and the activation of embryos from mice during delayed implantation. J. Reprod. Fert. 50, 1-8.

Pritchard, J.J. (1947) The distribution of ALP in the pregnancy uterus of the rat. J. Anat. 81, 352-366.

Steinetz, B.G., Manning, J.P., Giannina, T. \& Meli, A. (1967) Success or failure of early pregnancy in the rats as reflected by changes in uterine ALP activity. Enzymologia 33, 153-160.

Smith, M.S.R. \& Wilson, L.B. (1971) Histochemical observations on early implantation in the mouse. J. Embryol. exp. Morph. 25, 165-174. 